\title{
Dociekania
}

\section{Od ateizmu pojęcia do ateizmu bez pojęcia}

Szymon Wróbel

TEKSTY DRUGIE 2018, NR 2, S. 296-315

DOI: $10.18318 /$ td.2018.2.19

\section{Pojęcie ateizmu albo ateizm pojęcia}

Gilles Deleuze i Felix Guattari w słynnych fragmentach książki Co to jest filozofia? twierdzą, że religia istnieje tylko wtedy, gdy istnieje transcendencja, byt wertykalny lub państwo imperialne'. Filozofia, której żywiołem są pojęcia, szuka swego ożywienia w płaszczyźnie immanencji i im bardzie radykalna jest immanencja, tym bardziej ateistyczna filozofia. Autorzy książki Co to jest filozofia?, podążając tropem Dunsa Szkota, Spinozy, Nietzschego i Bergsona, w swym postulacie „dochowania wierności immanencji" są tak radykalni, że twierdzą, iż myślenie religijne tworzy pojęcie tylko na gruncie swego ateizmu. Dla filozofów problemem nie jest ani „śmierć Boga", ani „pojęcie ateizmu”, ale „ateizmu pojęcia”. Ateizm - w tej perspektywie - nie jest dramatem, lecz stanem "pogody ducha" filozofa i „zdobyczą filozofii”, rodzajem wiedzy radosnej. Wyrażenie „ateizm pojęcia” sugeruje, że myślenie

1 G. Deleuze, F. Guattari Co to jest filozofia?, przeł. P. Pieniążek, słowo/ obraz terytoria, Gdańsk 2000, s. 8.

\section{Szymon Wróbel -}

profesor na Wydziale

„Artes Liberales" UW

oraz w Instytucie Fi-

lozofii i Socjologii PAN w Warszawie. Psycholog i filozof. Ostatnio opublikowat:Polska pozycja depresyjna: od Gombrowicza do Mrożka i z powrotem (wyd. Universitas, Kraków 2015) oraz Filozofi terytorium. Polityka idei w myśli Leszka Kołakowskiego, Bronisława Baczki, Krzysztofa Pomiana i Marka J.Siemka (wyd. IFiS PAN, Warszawa 2016). Kontakt: wrobelsz@gmail.com 
jest z gruntu niereligijne, niedogmatyczne, unikające pokus transcendencji, zawsze zorientowane na świat i działanie.

W swym tekście będę starał się przemyśleć „ateizm pojęcia” rodzący - jak będę twierdził - rodzaj niepokojącego „kultu pojęcia”. Stawiam pytanie, czy „ateizm pojęcia” nie jest stale pozostałością po myśleniu teistycznym, który należy także przezwyciężyć? Czy ustawienie w centrum myślenia kategorii „pojęcia”, oraz skazanie filozofii na rodzaj uzależnienia od pojęć, nie jest świadectwem większej wierności wobec „filozofii” niż wobec myślenia? Będę też pytał o to, czy możliwe są religie w obrębie tego, co immanentne lub pozornie immanentne? Wreszcie stawiam pytanie, czy możliwy jest „ateizm poza pojęciem" lub „ateizm bez pojęcia"? To jednak zmusza mnie do zastanowienia się nad samą ideą pojęcia (the notion of concept) i możliwej obecności lub bycia „poza pojęciem”.

Mam świadomość, że „pojęcie” - szczególnie dla Deleuze'a i Guattariego - nie jest „poza życiem”, ale jest jednym z „trybów życia”. Pojęcia dla Deleuze’a i Guattariego nie są ani Platońskimi ideami, ani Heglowskimi podmiotami ujawniającymi podczas historii swoją treść (prawdę), ani nawet Wittgensteinowskimi "klasami” opartymi na podobieństwach rodzinnych. Pojęcia są „zwierzętami”, ,organizmami”, ,witalistycznymi siłami”. To, że człowiek żyje w kompletnie zaprojektowanym środowisku, nie oznacza, że odwrócił się od życia lub odwrócił porządek życia, lecz jedynie, że żyje on w pewien sposób. Dlatego "ateizmu pojęcia" nie przeciwstawiam , ateizmowi bez pojęcia”, o ile "pojęcie” nie przeciwstawia się „życiu”. Wiedząc to wszystko, wiemy jednak, że filozofia żyje „z pojęć" i „dla pojęć" i „,bez pojęć" praktyka myślenia jest niemożliwa. Pojęcia zatem, nawet zwitalizowane pojęcia, stale stanowią centrum działania filozofii. Czy jednak stanowią centrum działania praktyki ateistycznej?

Czym zatem jest „ateizm bez pojęcia”? „Ateizm bez pojęcia” jest praktyką i dotyczy „hexis ( $\check{\xi} \xi \varsigma)$ życia”, a nie samych „przekonań” lub „postaci pojęciowych". Takie postawienie sprawy wymaga ponownego przemyślenia pojęcia "praktyki”. Ateizm „poza pojęciem" wymaga bowiem zaangażowania w nowy rodzaj praktyki. Dla zwykłego ateisty obiektem wiary nie jest Bóg jako gwarancja jedności, racjonalności, celowości lub ładu świata, ale sam Świat bez żadnej gwarancji. Być może słowo „ateizm” oznacza po prostu prymat "koniecznej przygodności" w takim sensie, w jaki go dziś wyposaża Quentin Meillassoux ${ }^{2}$. W ateistycznym świecie czas nie jest uruchomieniem możliwości,

2 Q. Meillassoux Po skończoności. Esej o koniecznej przygodności, przeł. P. Herbich, Biblioteka kwartalnika Kronos, Fundacja Augusta hr. Cieszkowskiego, Warszawa 2015. 
to nie realność czasu tworzy realność zdarzeń, ale same wydarzenia pozwalają wyłonić się biegowi czasu. Tak rozumianym czasem nie rządzi żadna pozaczasowa zasada, np. zasada racji dostatecznej Leibniza, ten czas jest zdany na czystą immanencję swej poza-prawości i bez-pojęciowości.

Ostrze rozważań skieruję w trzy strony. Po pierwsze, podążając za myślami Bruno Latoura, zastanowię się na obecnością Boga w nowoczesności. Czwarta gwarancja świata nowoczesnego, w projekcie konstytucji nowoczesności, zaproponowanym przez Latoura, jest dziwnym oddzieleniem Boga od świata ${ }^{3}$. Będę starał się przemyśleć tę "dziwność” i to „oddzielenie”. Zastanowię się też nad konsekwencjami stanowiska Latoura, tj. pojęciem agnostycyzmu. Po drugie, podążając tropem filozofii Jean-Luc Mariona, zastanowię się nad związkiem ateizmu z szaleństwem oraz idolatrią a, w rezultacie, samą możliwością ateizmu nieidolatrycznego ${ }^{4}$. Wreszcie w kroku trzecim, głównie w odwołaniu do pomysłów Judith Butler ${ }^{5}$ Jacques'a Rancière'a ${ }^{6}$, spróbuję przemyśleć praktykę ateistyczną jako ściśle powiązaną z demokracją lub raczej „ekscesem demokraci”, co pozwoli mi wprowadzić i wyjaśnić pojęcie „nienawiści do ateizmu”, ukute na wzór i podobieństwo Rancièreowskiej „nienawiści do demokracji". Główną racją i stawką tego myślenia i tej krętej proateistycznej drogi, okrężnej drogi do ustanowienia ateizmu, jest przekształcenie „ateizmu pojęcia" w „ateizm performatywny".

\section{Ustanowienie ateizmu albo „Bóg na uwięzi"}

Pewną pomocą w uwolnieniu się od ateizmu pojęcia wydaje się socjologia powiązań Bruno Latoura. Latour, opisując za pomocą trzech gwarancji konstytucję nowoczesnego świata, wprowadza zaskakujący wątek teologiczny, nieoczekiwaną czwartą gwarancję nowoczesności - podwójne oddzielenia Boga od natury i społeczeństwa. „Czwarta gwarancja - pisze Latour - reguluje problem Boga poprzez usunięcie go na zawsze z podwójnej konstrukcji natury i społeczeństwa i pozostawienie go równocześnie widzialnym i mimo

3 B. Latour Nigdy nie byliśmy nowocześni. Studium z antropologii symetrycznej, przeł. M. Gdula, Oficyna Naukowa, Warszawa 2011.

4 J.-L. Marion Bóg bez bycia, przeł. M. Frankiewicz, Znak, Kraków 1996.

5 J. Butler Walczq̨ce słowa. Mowa nienawiści i polityka performatywu, przeł. A. Ostołowski, Wydawnictwo Krytyki Politycznej, Warszawa 2010.

6 J. Rancière Nienawiść do demokracji, przeł. M. Kropiwnicki, Instytut Wydawniczy Książka i Prasa, Warszawa 2008. 
wszystko gotowym do użycia"'. Zdecydowałem się to podwójne wzięcie w nawias Boga nazwać koncepcją „Boga na uwięzi”. W czwartej gwarancji konstytucji świata nowoczesnego Bóg jest bowiem niczym latawiec lub balonik, który znika tuż za horyzontem $i$ „w zasadzie" pozostaje poza widzialnym światem empirycznym, jednak ze względu na wieź łączącą go niewidoczną i sprężystą linką z planetą Ziemia stale może być przywołany do pomocy w wyjaśnianiu tego, co nie da się wyjaśnić ani za pomocą zwykłych „praw natury”, ani za pomocą magicznych „faktów społecznych".

Nowoczesność to porządek, w którym nie tylko to, co społeczne i to, co naturalne zostało oddzielone od siebie, ale nade wszystko to porządek wyjaśnienia, w którym niepotrzebna jest już "hipoteza Boga” jako przyczyny sprawczej lub formalnej dla ustanowienia "natury" lub „społeczeństwa”. Latour pisze szorstko: „Nikt nie będzie prawdziwie nowoczesny, dopóki nie zgodzi się trzymać Boga z dala od praw natury i praw Republiki”8. Czy to "trzymanie Boga z daleka od praw natury i społeczeństwa” oznacza jednak nadejście epoki ateizmu? Dlaczego istnienie Boga w nowoczesnym świecie zostało podtrzymane przy życiu, skoro to życie podtrzymywane jest jedynie kroplówkami metafizyki? Dlaczego Boga nie usunięto w sposób kompletny i ostateczny, tak by ustanowić wraz z konstytucją nowoczesności „prosty ateizm". Odpowiedź Latoura na to ważne pytanie jest następująca. Gdy dwoje rywalizujących „bliźniaków” - natura i społeczeństwo, zawieszono w próżni, w przypadku konfliktu między nimi nikt nie byłby w stanie rozstrzygnąć zwycięstwa i pierwszeństwa jednego z nich. Bóg jest zatem potrzebny dla uniknięcia wyrazistej i kłopotliwej symetrii między dwoma wcześniejszymi gwarancjami konstytucji. W świetle pierwszej gwarancji - natura, mimo że jest „skonstruowana”, istnieje tak jakbyśmy jej nie tworzyli. W świetle drugiej gwarancji - społeczeństwo, mimo że przez nas „zastane”, istnieje tak jakbyśmy je fabrykowali. Bóg potrzebny jest jako rozjemca w tej grze faktów naturalnych i społecznych.

„Transcendencja Boga - pisze Latour - oddalała go na tyle skutecznie, że nie zakłócał wolnej gry praw natury i praw społeczeństwa, zachowano jednak możliwość odwołania się do niego w przypadku konfliktu między prawami natury a prawami społeczeństwa" ${ }^{\text {. }}$ Zdaniem Latoura ten chytry

7 B. Latour Nigdy nie byliśmy nowocześni. Studium z antropologii symetrycznej, s. 52.

8 Tamże.

9 Tamże, s. 52. 
zabieg wygnania Boga ze świata, a jednocześnie trzymania go w depozycie, w odwodzie, na uwięzi pozwolił nowoczesnym stać się „ateistami” i „ludźmi religijnymi” jednocześnie. „Nowocześni mogli być od tej pory zarazem świeccy i pobożni"10. Konstytucja nowoczesności nie jest zatem nigdy „zakończona” lub „ostateczna”, albowiem stale naraża świat na produkcję tworów nieczystych i zmieszanych, co w rezultacie skutkuje zapraszaniem wielkiego rozjemcy na scenę. Nieuniknione i nienormalne powroty Boga na ziemię staną się od tego momentu „normą".

\section{Faktysze albo nowi czarodzieje}

Bogowie u Latoura powracają w książce zatytułowanej On the Modern Cult of the Factish Gods, w której kluczowe pytanie brzmi: jak to możliwe, by człowiek był rządzony przez wytwory swych własnych rąk - obrazy, rzeźby, figurki, dewocjonalia"? Latour twierdzi, i to nie jest dla nas zaskoczeniem, że fetysze są fabrykowane przez człowieka, ale twierdzi także, że status faktów nie jest inny niż status fetyszy. W książce poświęconej „wojnom o naukę”, zatytułowanej Nadzieja Pandory Latour żalił się, że ikonofile - tacy jak on, muszą się w świecie nowoczesnym stale bronić przed ikonoklastami. W tej samej książce Latour poruszył także delikatny problem agnostycyzmu ${ }^{12}$. „Obrazoburstwo - pisze - stanowi kluczową część każdej krytyki. Ale co rozbija młot krytyka? Idola. Fetysza. Czym jednak jest fetysz? Sam w sobie jest niczym, stanowi natomiast pusty ekran, na który błędnie nałożyliśmy nasze upodobania, nasz wysiłek, nasze nadzieje i pasje"13. Fetysz to „ludzkie" w przebraniu tego, co „nie-ludzkie”, to "człowiek" w przebraniu "maga". Co to oznacza? Oznacza to, że nie staniemy się ateistami nie tylko tak długo, jak długo pozostawimy przy życiu „transcendencję" - warunek religii, nie staniemy się ateistami, jak długo podtrzymywać będziemy samą gwarancję różnicy między immanencją i transcendencją.

Tu docieramy do sedna złożonej argumentacji Latoura: fetysz i fakt mają nie tylko wspólne korzenie, ale także podobną sprawczość. Fakt, dla Latoura, jest czymś, co jest zarazem wytworzone (fabricated) jak i niewytworzone

10 Tamże, s. 53.

B. Latour On the Modern Cult of the Factish Gods, trans. C. Porter, H. MacLean, Duke University Press, Durham, N.C. 2010. (redaktor naukowy przekładu) i in., Wydawnictwo Naukowe UMK, Toruń 2013, s. 329-345. 
(notfabricated). Fetysz, podobnie, jest czymś wytworzonym i niewytworzonym równocześnie. Ta wspólna genealogia, ale też moc sprawcza faktów i fetyszy pozwala Latourowi na wprowadzenie nowego pojęcia - faktysza. Faktysz to coś, co musi być ciągle na nowo wytwarzane, produkowane, fabrykowane, przez co staje się niezbędne do działania i życia.

Kim jest zatem obrazoburczy krytyk? I jak fakty mają się do fetyszy? Z czym walczy krytyk - z faktami?, z fetyszami za pomocą faktów?, faktyszami? Obrazoburca to ktoś, kto naiwnie wierzy, że fakty, których użył i które sam spreparował, aby zniszczyć idola, mogą istnieć autonomicznie, bez pomocy jego działań. Tak jednak nie jest, wygaśnięcie działań na równi niszczy fakty i fetysze. Fakty to fetysze, które zapomniały o swoim fetyszystycznym pochodzeniu i charakterze. Czy nie przypomina to rozumowania z Dialektyki oświecenia Adorna i Horkheimera - jeśli krytykę rozumiemy jako narzędzie wyzwolenia człowieka z wiary w złe siły, demony i czarownice, w ślepe przeznaczenie, a zatem jako emancypację od lęku i trwogi, to największą przysługą, jaką może oddać światu myślenie, tj. ateizm pojęcia, jest demaskowanie tego, co się obecnie nazywa rozumem, tj. fabryką faktów ${ }^{14}$. Po tej demaskacji rozumu „czar rozumu" - manufaktura faktów i "rozum czarów” - manufaktura idoli, stają się jednym i tym samym.

Jakie jest zatem właściwe stanowisko Latoura? Po czyjej jest on stronie? Czy Latour jest ateistą? Czy też proponuje zawieszenie mocy krytycznych i wycofanie się z wszelkich prób niszczenia bałwochwalstwa, tj. zajęcie pozycji agnostyka? Czym jednak jest domniemany agnostycyzm Latoura? Czy jest on rodzajem sceptycyzmu, odmową zajęcia stanowiska, skryciem się za formułą „nie wiem”? Twierdzę, że ten agnostycyzm, jawnie przeciwstawiający się ateizmowi i deizmowi równocześnie, jest jawną rewindykacją fetysza (idola) i deprecjacją faktu (stwierdzenia), a zatem w rezultacie dowartościowaniem działań czarodzieja-magika i odwartościowaniem działań kontr-magika, przeciw-czarodzieja. Agnostycyzm Latoura zdradza pewną oczywistą słabość, kiedy zadajemy proste pytanie, kto korzysta z tego agnostycyzmu? Na usługach kogo jest ten agnostycyzm? W jakim interesie dokonuje się to zrównanie faktu i fetysza? Przejście od "ateizmu” do „agnostycyzmu”, jeśli dokonuje się przez pośrednictwo sceptycyzmu, tj. uznania ułomności każdej formy wiedzy, byłoby przejściem dokonanym po „wojnach o naukę” i rezultatem tych wojen, przejściem ujawniającym jedynie naszą niewiarę

14 T.W. Adorno, M. Horkheimer Dialektyka oświecenia. Fragmenty filozoficzne, przeł. M. Łukasiewicz, IFiS PAN, Warszawa 1994. 
w „wiedzę” i stałą wiarę „w wiarę”. Agnostycyzm byłby zatem stanem „po wojnie”. Przypominałby raczej „rozejm” niż „wieczysty pokój”.

Wniosek, jaki należałoby wyprowadzić z tej części rozważań, brzmiałby następująco. Wydaje się, że kluczową sprawą dla podtrzymania istnienia Boga w nowoczesności jest relacja między ikonofilią i idolatrią, fetyszem i rzeczą, złudzeniem i ideologią, świadomością i praktyką, świadomością naiwną a świadomością krytyczną. Teologia wycofuje się z Boga rozumianego jako obraz, ale nie z Boga rozumianego jako przyczyna. Wspólnota wycofuje się z świadomego przedmiotu kultu Boga, ale nie z praktyk religijnych i językowych, które kontynuowane są poza obszarem religii. Sztuka i nauka wycofują się z kultu obrazów i diagramów, ale nie z samego rozróżnienia na fakt (rzecz) i fetysz (przedstawienie). Filozofia wycofuje się ze świadomości naiwnej, ale nie ze świadomości krytycznej, pozostawia zatem rozumną ideę Boga. Wreszcie psychoanaliza wycofuje się z wiary jako „pewnej iluzji” bez pewnej przyszłości, ale nie ze struktury, która jest nieświadoma. W rezultacie tych odwrotów i przewrotów, Bóg w nowoczesności staje się wielkim „obecnym nieobecnym”, ,podmiotem”, którego się stale poszukuje w grze w chowanego. Bóg stał się bowiem jednocześnie sprawczy i impotentny, skryty i jawny, nieobrazowy i pojęciowy, niewyrażalny, a jednak gwarantujący wszelką wyrażalność i pojmowalność.

Ta przewrotna obecność Boga, zdaniem Latoura, ma tworzyć pozorną „moc nowoczesnych”. Latour pisze paradoksalnie: „[Nowocześni] nie stworzyli natury, wytworzyli społeczeństwo; wytworzyli naturę, nie stworzyli społeczeństwa; nie stworzyli ani jednego, ani drugiego, ponieważ wszystko stworzył Bóg; Bóg niczego nie stworzył i wszystko jest jego dziełem"15. To bardzo pokrętne, albowiem oparte jest nie na „logice wykluczania”, ale na "logice chowania i ujawniania”. Nowocześni stali się niezwyciężeni, ponieważ obsadzili wszystkie możliwe pozycje, choć wszystkie także zakwestionowali, wytworzyli swoistą ekonomię checks and balance. W tej ekonomii i teologii jednocześnie Bogu przypada rola arbitra nieskończenie oddalonego, sędziego całkowicie bezsilnego i suwerennego.

\section{Bóg albo jego nowoczesne losy}

Bóg jest zatem swoim kosmosem, ale magowie tworzą nowoczesne losy Boga. Jakie są losy Boga w nowoczesności, po Descarcie, Spinozie i Leibnizu? 
Mówiąc w największym skrócie, zaryzykowałbym tezę, że Ludwig Feuerbach, Max Stirner, Karol Marks opierają się na skonstruowanym przez Hegla utożsamieniu Boga $\mathrm{z}$ wiedzą absolutną. Być może $\mathrm{z}$ tego powodu przeprowadzają oni nieskuteczną i nieefektywną „krytykę Boga”, w celu oczyszczenia jego pojęcia z jego zawartości, na korzyść innego pojęcia, które okazuje się wpisane w zastany system metafizyczny.

Feuerbach w słynnym tekście $O$ istocie chrześcijaństwa powiada wprost: „Aby wzbogacić Boga, człowiek musi stać się biednym; aby Bóg był wszystkim, człowiek musi być niczym"16. To ponowna reaktywacja gry w chowanego i gry o sumie zerowej jednocześnie. To uruchomienie nieskutecznego języka krytyki nie dlatego, że krytyka nie dotyka istoty rzeczy lub warunków możliwości pojęcia Boga; nieskuteczność krytyki wynika z tego, że nie obala ona konstytucji świata nowoczesnego, tj. czwartego warunku podziału terytorium. Ta krytyka nie jest dość diagnostyczna i detektywistyczna wobec milczących warunków nie tylko istnienia Boga, ale i samego podziału terytorialnego świata. Ta krytyka jedynie odwraca relację na korzyść - „upadłego człowieka”, „podziału pracy”,,,twórczości”, ,nie-mocy”, etc. Kiedy Marks głosi krytykę religii jako wstęp do wszelkiej krytyki ideologii i gdy uznaje religię za ideologię par excellence lub za wzorcową formę wszelkiej ideologii, to formułuje pytanie o możliwość ukonstytuowania się społeczeństwa ateistów jako społeczeństwa bez złudzenia ideologicznego, bez mistyfikacji, bez odwoływania się do kategorii pozoru ${ }^{17}$. To pytanie jest jednak stale zadawane z perspektywy nowoczesnej konstytucji świata i przy milczącej akceptacji tej konstytucji. Komunizm to społeczeństwo, które nadchodzi „po ateizmie”, w chwili gdy „ateizm pojęcia” staje się zbyteczny.

Skąd zatem ten upór trwania struktur teologicznych? Czy wynika on z tego, że sam kapitalizm przyjął formę kultu? Czy wzorem Waltera Benjamina należy ujrzeć w kapitalizmie religię, formę permanentnego kultu, celebrację obrządku bez wytchnienia i bez łaski, w którym zaciera się granica między dniami świątecznymi a roboczymi? Czy kapitalizm to system nieprzerwanego święta, kultu fetysza, towaru, idolatrii zwielokrotnionej i bezgranicznej ${ }^{18}$ ? Być może nie chodzi o religię, ale dziwną kontaminację religii z ideologią, ideologii z ekonomią, polityki z epistemologią. Być

L. Feuerbach O istocie chrześcijaństwa, przeł. A. Landman, PWN, Warszawa 1959, s. 76.

K. Marks Przyczynki do krytyki heglowskiej filozofii prawa, w: K. Marks, F. Engels Dzieła, t. 1, Książka i Wiedza, Warszawa 1960, s, 243-307.

W. Benjamin Kapitalizm jako religia, przeł. P. Mościcki, „Krytyka Polityczna” 2007 nr 11/12. 
może z powodu tej kontaminacji Jacques Derrida pisze o Marksie: „Religia [...] nigdy nie była dla Marksa jedną z wielu form ideologii”. Czym zatem była? No cóż była widmem, widmowym Bogiem, fuzją religii i ideologii: „teologizującą fetyszyzacją, która zawsze wiąże nieodłącznie ideologię z religią (z idolem lub fetyszem) jako jej zasadniczą figurą, swego rodzaju „widmowym bogiem” (Thou visible god), którego się wielbi i do którego zanosi się modły, prośby, błagania"ı9. To, co religijne nie jest tylko produktem fantomowym, albowiem dostarcza paradygmatycznego modelu dla procesu produkcji fantomu. Derrida nie pisze o zwykłym ateizmie, pisze raczej o „quasi-ateistycznej suchości mesjanistyczności”, która jest „warunkiem religii Księgi"20.

Na uwagę zasługuje też fakt, że spektralna i widmontologiczna lektura Marksa, dokonana przez Derridę, wyczerpuje się „na pojęciu” $\mathrm{i}$ „w pojęciu”. "Zasadniczo istnieje bez wątpienia - pisze Derrida - jedno widmo, widmo widm. Jest ono jedynie pojęciem, a nawet nie tyle pojęciem, ile niejasnym, «negroidalnym» przedstawieniem pojęcia szerszego i obejmującego więcej niż wszystkie inne"21. To pojęcie nie-do-pojęcia jest pojęciem-widmem kapitalizmu. Derrida pisze z lekkością: „Nominalizm, konceptualizm, realizm - wszystko to załamuje się za sprawą Rzeczy lub Nie-rzeczy zwanej widmem"22. W tym rzecz jednak, że nic się nie załamuje, wierząc w widma i duchy, stale pozostajemy w obrębie skrajnego realizmu pojęciowego. Spekulacja zawsze spekuluje na temat widma-pojęcia. W tym sensie spekulacja zawsze ma charakter teologiczny. Widmo komunizmu ściga się z widmem wartości wymiennej, ale oba widma odnajdują się w pojęciu. Czytanie Manifestu komunistycznego przez Tymona Ateńczyka Williama Shakespeare'a musi skończyć się konspiracją religijną, tajemnymi kultami, posępnymi liturgiami opartymi na imprekacji. Nasze myślenie o kapitalizmie nie musi się jednak kończyć na kulcie obrzędowości, w której rolę głównego cielca, idola, fetysza pełni, towar, a rolę głównego „widma” wartość wymienna ${ }^{23}$.

19 J. Derrida Widma Marksa. Stan długu, praca żałoby i nowa Międzynarodówka, przeł. T. Załuski, PWN, Warszawa 2016, s. 78.

Tamże, s. 268-269.

Tamże, s. 223. Tamże.

23 W sprawie "ateizmu Derridy" patrz: M. Hägglund Radical Atheism: Derrida and the Time of Life, Stanford University Press, Stanford 2008. 


\section{Szaleństwo ateizmu albo zwykła pomyłka}

Myślenie teologa apofatycznego Jean-Luca Mariona wydaje się być oddalone o lata świetlne od myślenia nowego materialisty i nominalisty, agnostyka Bruno Latoura. Jednak obaj myśliciele spotykają się w odkryciu narastających wątpliwości dotyczących możliwości ustanowienia nowoczesnego ateizmu, ateizmu w nowoczesności i nowoczesności poprzez ateizm. Latour i Marion uświadamiają nam, że nie ma "łatwego ateizmu", nie ma „ateizmu prostego", „ateizmu jako takiego". Ateizm zawsze wymaga wysiłku. Czy oznacza to, że ateizm jest zawsze trudnym ateizmem?

Zdaniem Mariona, zamiast pytać, czy „Bóg umarł” - umarła „nieskończoność” lub umarł „rozjemca”, należy z większą korzyścią dla myślenia zapytać, pod jakimi warunkami twierdzenie „Bóg umarł”, staje się możliwe do pomyślenia i wypowiedzenia? Jeśli to, co nazywamy „Bogiem” umiera, wtedy gdy ogłasza to pewien "szaleniec" rozradowanym ludziom, tak jak to jest w opowieści Friedricha Nietzschego, to czy ów „Bóg”, nie był od zawsze tylko „pozorem Boga”, nie-Bogiem? Człowiek szalony powiedział, że „Bóg umarł”, pisze Nietzsche, jakby powtarzając formułę Thomasa Hobbesa - „Człowiek szalony powiedział sobie w swym sercu, że nie ma takiej rzeczy, jak sprawiedliwość; i czasem mówił to również głośno [...]"24. Jeśli pamiętamy, że w rozumowaniu Latoura Bóg jest gwarancją rozdziału, to kwestia ateizmu zaczyna nam się jawić jako kwestia zgody na szaleństwo i niesprawiedliwość. Zapamiętajmy ten związek szaleństwa i ateizmu, albowiem wrócimy do niego na końcu.

Marion formułuje twierdzenie na pierwszy rzut oka niezrozumiałe: nic nie jest równie obce „śmierci Boga" jak powszechny ateizm² ${ }^{25}$, tylko Bóg-symptom został przezwyciężony, porzucona została moralność jako gra znaków. Co to jednak oznacza przezwyciężyć pozór? W jakim sensie powszechny i „zwyczajny ateizm” jest obcy śmierci Boga? W celu odszukania odpowiedzi na te pytania musimy raz jeszcze na chwilę zwrócić się w stronę lektury Nietzschego.

Nietzsche ogłosił „śmierć Boga”, jednak niewiele wiemy o człowieku ogłaszającym ten zgon ${ }^{26}$. W paragrafie 125 Wiedzy radosnej szaleniec mówi:

24 T. Hobbes Lewiatan, czyli materia, forma i władza państwa kościelnego i świeckiego, przeł. Cz. Znamierowski, Fundacja Aletheia, Warszawa 2005, s. 227-228.

25 J.-L. Marion Idol idystans, przeł. W. Starzyński, U. Idziak-Smoczyńska, Wydawnictwo WAM, Kraków 2016, s. 40-86. w: tegoż Drogi lasu, przekł. zbiorowy, Aletheia, Warszawa 1997, s. 172-173. 
„Bóg umarł”, jednak natychmiast oznajmia skandaliczność tego wydarzenia - „Zabiliśmy go - wy i ja! Wszyscy jesteśmy jego zabójcami! Lecz jakże to uczyniliśmy? Jakżeż zdołaliśmy wypić morze?"27. Dla pomiotu nowoczesnego morderstwo na Bogu jest trudne do pomyślenia, albowiem narzucone jest mu już tak silne skojarzenie Boga z nieskończonością, Boga z Bogiem równocześnie obecnym i nieobecnym, transcendentnym i immanentnym, że jego eliminacja wydaje się niemożliwa.

Kto zatem umiera, gdy pozornie umiera Bóg? Po „śmierci Boga” zmierzch zapada nad idolem. Podmiot nie wie jednak, jak odróżnić idola od ikony, rzeczywistość od pozoru. Podmiot nadal pozostaje więźniem idolatrii. Podmiot staje się niewolnikiem faktysza, tj. dziwnego zespolenia religii, ideologii i nauki. Podmiot odrzuca jedynie to, co zdolny jest sam skonstruować, a skonstruować jest zdolny tylko pojęcie lub obraz, bo sam sądzi, że jest „obrazem”, że został stworzony „na obraz i podobieństwo Boga”. Ta niezdolność pomyślenia siebie jako czegoś innego niż obrazu oraz Boga jako „tylko obrazu”, musi skazywać nowoczesność na stałe zagrożenie szaleństwa. Szaleniec Nietzschego szuka Boga „po śmierci Boga”. To w istocie czyste szaleństwo. Czyżby gwarancja sprawiedliwości i symetrii przestała działać? I czy tylko szaleniec jest zdolny odkryć to unieważnienie, unieruchomienie lub unieczynnienie teologicznej gwarancji? Czy tylko szaleniec jest zdolny stać się ateistą? Czy "ateizm” jest innym imieniem „szaleństwa"?

Należy zatem poszukiwać ateizmu nie-idolatrycznego. Czy taki jednak w ogóle istnieje? Ateizm stałby się na zawsze idolatryczny, gdyby zakładał milcząco pewnego idola, na którego kieruje swoją negację, ideę Boga poddaną podważaniu. Byłoby tak, gdyby - odwołując się do języka psychoanalizy ateizm oznaczał jedynie wyparcie (Verdrangung), zaprzeczenie (Verleugnung) lub wykluczenie (Verwerfung) Boga ${ }^{28}$. Śmierć Boga stanowiłaby w takiej sytuacji jedynie odwróconą postać religijnych kultów.W takim ateizmie nic się nie zmienia poza krytyką, dzięki której Bóg zastyga w swoim obrazie. Dlatego

F. Nietzsche Wiedza radosna, przeł. L. Staff, J. Mortkowicz, Warszawa 1907, s. 151-220, 287-362. nalnej kulturze świeckiej, w której nikt nie jest gotów publicznie przyznawać się do swojej wiary, fundamentalna struktura wiary jest wszechobecna - wszyscy skrycie wierzymy. [...] Ateizm nie stanowi poziomu zero zrozumiałego dla każdego, gdyż oznacza tylko nieobecność (wiary w) Boga - może nie ma nic trudniejszego nad utrzymanie stanowiska, bycia prawdziwym materialistą. Ponieważ struktura wiary ma postać fetyszystycznego Spaltung und Verleugnung", [rozszczepienia i negacji] ("wiem, że nie ma wielkiego Innego, ale... skrycie wierzę w Niego"). S. Žižek O wierze, przeł. B. Baran, Aletheia, Warszawa 2008, s. 10. 
Marion słusznie powiada, że idol przedłuża swój żywot wtedy, gdy umiera Bóg, ponieważ sama śmierć potwierdza jego obecność. Ateizm nie może wyczerpywać się w pracy negacji. Potrzebujemy pozytywnej formuły ateizmu.

W Zmierzchu bogów Nietzschego czytamy - „Jak to? Jest-że-człowiek jeno pomyłką (Fehlgriff) Boga? Lub Bóg tylko omyłką (Fehlgriff) człowieka, a pojęcie Boga wynaleziono jako przeciwieństwo pojęcia życia"29. Co jest jednak błędem czego? Czy Bóg jest „zwykłym błędem” ludzkiego intelektu? Czy też intelekt jest „niezwykłym błędem” natury, która powołała do życia organ, niesłużący bezpośrednio przetrwaniu, ale pomnażaniu ludzkich zmartwień i wątpliwości? Czy należałoby mówić o „wiedzy radosnej” ateizmu, którą unieważniają ascetyczni kapłani, czy też „radosnej wierze” chrystianizmu, którą zabija pesymizm ateizmu? Należy się spytać o złożone relacje ateizmu $\mathrm{i}$ wiedzy radosnej, tj. na czym polega ateistyczna radość wiedzy po śmierci Boga? Czy na otwartym kulcie ciała jako miejsca nieustannej fiesty? Czy radość wynika z unieważnienia prymatu Całości, która czuwa nad prawomocnością wszystkiego i wszystkich? Bóg umarł, i oznacza to, że nie tyle wszystko jest dozwolone, ile wszystko na nowo jest możliwe? Jak uroczystości żałobne po śmierci Boga zamieniają się w wielkie i wszystko obejmujące radosne święto wiosny? Jak „zwykły ateizm” zrywa z rytuałami „trudnego ateizmu”, „ateizmu resztkowego", ,imitatywnego", ,szczątkowego", ,rezydualnego" ${ }^{30}$ ?

\section{Śmiertelny Bóg albo "ateizm płaski"}

Stałe zagrożenie istnienia Boga śmiercią - to temat niezwykle intrygujący dla inteligencji Mariona. Nie chodzi o to, że człowiek zabił obraz, chodzi raczej o to, że coś, co może zostać zabite, jest zawsze tylko obrazem. Bóg, który może umrzeć, ukrywa w sobie, nawet wtedy, gdy jeszcze nie umarł, pewną słabość. Taki śmiertelny Bóg odkleja się od swego pierwotnego pojęcia. Bóg umiera zatem z powodu złego pojęcia. Jest rodzajem grzeczności z jego strony, gdy wypełni przeznaczenie swojej fałszywej immanentnej skończoności, tj. przeznaczenie złego pojęcia Boga. Bóg, który decyduje się umrzeć, umiera bowiem od początku zaistnienia swojego fałszywego pojęcia ${ }^{31}$. Czy zatem Bóg nie umiera nigdy? I fałszywi bogowie umierają zawsze i bez końca?

29 F. Nietzsche Zmierzch bożyszcz, przeł. S. Wyrzykowski, J. Mortkowicz, Warszawa 1907, s. 45. entin Meillassoux, Edinburgh University Press, Edinburgh 2011.

31 J.-L. Marion Idol idystans. 
I w tym znaczeniu nigdy nie rodzi się „prawdziwy ateizm” i nikt nigdy nie był „zwykłym ateistą”? Czy w obliczu „Boga nieśmiertelnego” należy uznać, że ateizm jest niemożliwy i tylko szaleniec (raz jeszcze) może ogłosić śmierć Boga? Kim jest ateista w obliczu Boga nieśmiertelnego? Być może skonfrontowani z lawiną tych pytań musimy się spytać raz jeszcze o samo pojęcie ateizmu.

Ateizm w pierwotnym sensie oznaczał osobę opuszczoną przez bogów. W tym znaczeniu św. Paweł mówi np.: „Pamiętajcie, że w owym czasie byliście bez Chrystusa, wyłączeni ze społeczności Izraela i bez udziału w przymierzach obietnicy, nie mający nadziei, ateistami bez Boga na tym świecie" (Ef 2,12). Kiedy Agamben powraca dzisiaj do istot pozbawionych możliwości zbawienia, pisząc o zmarłych i nieochrzczonych dzieciach, pozbawionych możliwości oglądania splendoru Boga, istotach pogrążonych we wiekuistym zapomnieniu o Bogu, istotach obojętnych na jakąkolwiek formę zbawienia, szachrajach i próżniakach, bohaterach powołanych do życia przez Roberta Walsera, „bezbożnikach” doświadczających swej znikomości i „tego, co jest nie do naprawienia”, być może reanimuje pierwotną formułę ateizmu ${ }^{32}$. Ateizm przyjmuje jednak także inne oblicze. Mówimy o ateiście jako osobie „porzuconej przez Boga”, ale mówimy też o ateiście jako osobie "porzucającej Boga". Prototypem tej pierwszej jest Hiob, prototypem tej drugiej - przyjmijmy - jest Prometeusz. Oczywiście biblijny Hiob nie traci wiary, ale jest wystawiony na pokusę jej utraty. Oczywiście mitologiczny Prometeusz nie wychodzi poza oddziaływanie bogów, ale staje po stronie człowieka przeciw bogom. To co łączy Hioba i Prometeusza to akt porzucenia - porzucenie człowieka przez Boga lub porzucenie bogów przez herosa. Należałoby, w kontekście tych dwóch opowieści - o Hiobie i Prometeuszu, zapytać, czy „ateizm nowoczesny" i „ateizm w nowoczesności” nie różni się od "ateizmu tradycyjnego" tym, że uwikłany jest w akt porzucenia, który przypomina bardziej "gest Prometeusza” niż Hioba, tj. akt dokonujący się w imię ludzkiej suwerenności i samowystarczalności? Konstytucja nowoczesności, nie tyle tworzyłaby - jak sugeruje Latour - „czystość” i „osobność królestw”, ile „logikę suwerenności”. Nowoczesny ateista przypomina bardziej Robinsona Crusoe i jego sobowtóry - człowieka zagubionego na Marsie na przykład, człowieka który jest w stanie o własnych siłach, za sprawą swej domniemanej genialności, wygenerować całą technikę niezbędną do przeżycia. 
Nowoczesny ateizm nie jest ateizmem człowieka samowystarczalnego, ani nawet Prometeusza, który buduje samodzielnie wszystkie instrumenty użytkowe, ani konsekwencją wycofania się Boga na pozycje bytu osobnego, ukrytego i milczącego. Nowoczesny ateizm to "ateizm płaski”, to jawny brak perspektywy oceniającej, wynik zachwiania wszelkich hierarchii i zakwestionowania porządku wertykalnego.

\section{Ateizm pojęciowy albo fabrykowanie idoli}

Oryginalność poglądów Mariona, na tle konstytucji nowoczesności naszkicowanej przez Latoura, polega na tym, że Marion widzi nowoczesność, jako formację, która jednak coś wyklucza i od czegoś nas uzależnia. Nowoczesność nie tyle trzyma w rezerwie Boga, ile próbuje go nieskutecznie zamordować. To nie tyle wygodna "rezerwacja” miejsca "dla Boga” lub „po Bogu”, ile nieskuteczne i stale ponawiane, czysto pojęciowe „mordy na Bogu”, są przyczyną naszego „pozornego ateizmu" $\mathrm{i}$, ateizmu pozoru". Jesteśmy „paradoksalnymi ateistami",, ,ateistami w rozkroku”,,,bałamutnymi handlarzami" pewnej szczególnej pojęciowej idolatrii - przekupnymi poganami handlującymi pojęciami - „ateizmem pojęcia”, albowiem to „pojęcie” jest naszym nowym „fetyszem”. Ważność Mariona wynika właśnie z tego, że pozwala nam wrócić do formuły „ateizmu pojęcia” i zastanowić się na „ateizmem pojęciowym” raz jeszcze. Już nie nad „pojęciem ateizmu”, ale właśnie „ateizmem pojęcia”.

Dla ustanowienia ateizmu, w nowoczesnym sensie tego słowa, w znaczeniu doktryny, która zatrzymuje Boga w rezerwie, wymagane jest dowodzenie, tj. myślenie pojęciowe. To jednak wymaga odwołania się do pojęcia Boga, które staje się częścią dowodu, dostarczającego mu ostatecznego punktu oparcia. Jeśli Bóg pokrywa się ze swoim pojęciem, to jego zaprzeczenie nie wyeliminuje Boga w sposób ostateczny i absolutny, lecz jedynie zakwestionuje sens Boga, który Bóg odziedziczył po swoim pojęciu. W celu ostatecznego wyeliminowania Boga i pojęciowego ustanowienia ateizmu, należałoby dokonać wyczerpującego wyliczenia wszystkich możliwych pojęć Boga, by opierając się na nich, wszystkie je odrzucić i unicestwić.

Ateizm pojęciowy nie jest w stanie wyczerpać nieskończoności pojęcia Boga. Ateizm byłby możliwy, gdyby myślenie dotarło do kresu. Ateizm pojęciowy byłby wykonalny, gdyby spełnił warunek ateizmu pojęcia. Nie spełnia go jednak, stanowi jedynie rodzaj „kresu myślenia”, stan „po wyczerpaniu” treści pojęcia Boga. Ateizm pojęcia jest intelektualnym wyczerpaniem. Idolatria pojęciowa zostaje zwalczona lub przezwyciężona inną idolatrią, 
poprzez zmianę jednego obrazu na drugi, dzięki czemu Bóg wycofuje się na coraz dalsze peryferie, ale nigdy nie zamiera, staje się jedynie coraz bardziej enigmatyczną „zmienną zależną".

Wyprowadźmy z tego fragmentu ważną konkluzję: ateizm stałby się konkluzywny $i$,autentycznie morderczy" jedynie rezygnując z operacji na pojęciu „Bóg”. Kiedy Nietzsche pisał: „Obawiam się, że nie uwolniliśmy się od Boga, ponieważ nadal wierzymy w gramatykę"33, być może miał właśnie na myśli niemożliwość dokonania ostatecznego mordu. Czyż zresztą perypetie filozofii XX wieku nie upewniają nas w tym, że w chwili, kiedy próbowała ona wyeliminować absolut teologiczny - Boga, powoływała ona do życia inny absolut w postaci Języka? Problem w tym jednak, że możemy mówić o Bogu tylko na podstawie pozorów, jakie ukazuje nam idol, zepchnięty do poziomu epifenomenów lub symptomów, tj. przemysłu idolatrycznego, tj. pewnej siły podtrzymującej fabrykę idoli. Język umykał przed nami, rozpraszając się w materialnych aktach mowy, w taki sam sposób jak Bóg rozpraszając się w swoich nieoczywistych śladach. Idolatria znika tylko poprzez nieobecność „pojęcia Boga” albo nieobecność samego pojęcia „pojęcia”, tzn. także ateizmu pojęcia. Twierdzę, że są powody, aby wbrew optymistycznej diagnozie Deleuze’a i Guattariego mówić nie tyle o „ateizmie pojęcia”, ile o „teizmie pojęcia”34.

F. Nietzsche Zmierzch bożyszcz, s. 38 .

Daniel Barber w swej intrygującej książce na temat "ateizmu" Deleuze'a proponuje odmienną interpretację, bardziej życzliwą Deleuzowi. Dla Barbera "produkcja bogów" jest produkcją wartości, która doprowadza do dewaloryzacji działania, za pomocą którego wszelka wartość jest wytwarzana. Bóg, który jest idolem, odtwarza się w urzeczowionej wyobraźni, która od tej pory staje się martwa. Taki jest też sens, zdaniem Barbera, słynnego stwierdzenia Nietzschego: „nie wierzcie tym, którzy mówią o innych światach”. Dyskurs Deleuze'a to dyskurs na temat samej możliwości nowości, a zatem twórczości. Ten dyskurs nie powinien być traktowany i interpretowany jako jeszcze jedna opowieść na temat sekularyzacji, racjonalizacji czy modernizacji świata. Filozofia Deleuzéa jest polityczna, ale nie dlatego, że myśli o "polityce”, filozofia Deleuze'a jest polityczna, ponieważ kategorycznie nalega na wierność immanencji, tj. zachowanie ścisłego związku między immanencją, wyobraźnią a światem. Wyobraźnia należy do świata, ale świat jest wyobraźnią. Immanencja Deleuze'a jest myślana przeciw teologii chrześcijańskiej, a jednocześnie nie może być redukowana do świeckich, postsekularnych kategorii. Zdaniem Barbera filozofia Deleuze'a jest operacją na praktykach językowych, które są nierozerwalnie powiązane z praktykami religijnymi. Ta myśl jest już obecna u Spinozy i Nietzschego. W rezultacie "ateizm" Deleuze'a staje się samą artykulacją "przestrzeni immanencji”, ale jest to także „ateizmem", który przyjmuje immanencję jako stały problem dla myślenia. Ten ateizm wymaga od nas zdolności do wyobrażania sobie zmiany bez odwoływania się do idei "transcendencji”, żąda „ „immanencji zróżnicowanej i różnicującej się", „wewnętrznie poróżnionej". Ta immanencja może się fałdować i sama zmieniać, bez konieczności odnoszenia się do czegoś poza nią. Dla Barbera, główne pytanie brzmi zatem: co to znaczy mówić o immanencji, 


\section{Praktyka albo nienawiść do ateizmu}

W istocie musimy się zgodzić z Marionem, kiedy pisze, że należy pytać o możliwość ateizmu. Zgadzamy się z nim, ale tylko pod warunkiem, że rozszerzymy formułę „możliwości”. Należy bowiem pytać nie tylko o to, kiedy ateizm jest możliwy, tj. pod jakimi warunkami ateizm jest możliwy? Należy nie tylko pytać, jakie są transcendentalne warunki (Kant) lub racje dostateczne (Leibniz) ateizmu? Należy pytać nie tylko o to, jakie są źródła i motywacje ateizmu? Musimy jeszcze zapytać o to, co może ateizm? Pytamy stanowczo także: jakie są rozpoznane i nierozpoznane moce ateizmu? Pytamy wreszcie: czego chce ateizm? Do czego zdolny jest ateizm? Czy ateizm jest zdolny do rozbrojenia już nie tyle teizmu, ile wszystkich formuł konstytucji świata nowoczesnego? Czy tylko ateizm znajduje się w procesie nieustannego dekonstruowania samego siebie i nigdy nie osiada na zdobytych pozycjach, w spoczynku?

Powiada się, że człowiek współczesny - wedle wzorca zaproponowanego przez Rolanda Barthes'a i Michela de Certeau - stał się nie tyle „ateistą", ile „szalonym podmiotem wiary” bez „obiektów wiary”, tj. konsumentem dowolnych przedmiotów wiary, sam pozbawiony wszelkiej profetycznej wiary ${ }^{35}$. Należy zatem zapytać, czy stawką ateizmu jest ustanowienie społeczeństwa radykalnej demokracji? Czy „nienawiść do ateizmu” jest tego samego rodzaju, co „nienawiść do demokracji”36. Należy zatem zapytać nie tylko o związek ateizmu z pojęciem, ale także o związek ateizmu z demokracją i praktyką demokracji, a nawet z samym pojęciem „polityki”. Czy nadejście a-teizmu, jest swego rodzaju zastąpieniem „religii” "polityką", i stworzeniem niebezpiecznego pretekstu do nadejścia „polityk profetycznych”? Odkąd polityka stała się manufakturą do tworzenia nowych „obiektów do wierzenia", religia przekształciła się w politykę samozachowania lub samozniszczenia.

To ważna kwestia w kontekście wychodzenia poza pojęciowość filozofii. Twierdzę bowiem nie tylko, że „ateizm bez pojęcia” nie jest „postawą wiary”,

która jest zdolnością do samoróżnicowania się? Barber odpowiada: oznacza to, że immanencja jest "bez obiektu” i „bez ostatecznego celu”, bez wyznaczonego przeznaczenia” (D. Colucciello Barber Deleuze and the naming of God. Post-Secularism and the Future of Immanence, Edinburgh University Press, Edinburgh 2014). Zgadzając się z przesłankami, na których opiera się ta interpretacja, brakuje nam tu przejścia od „pojęcia ateizmu” do „praktyki ateistycznej”, szczególnie jeśli centralne okazują się praktyki językowe (nazywanie) i praktyki religijne (ceremonie).

R. Barthes Mitologie, przeł. A. Dziadek, KR, Warszawa 2000; M. de Certeau Wynaleźć codzienność. Sztuki działania, przeł. K. Thiel-Jańczuk, Wydawnictwo UJ, Kraków 2008.

36 J. Rancière Nienawiść do demokracji, przeł. M. Kropiwnicki, Instytut Wydawniczy Książka i Prasa, Warszawa 2008. 
tak jak wszelkie inne postawy religijne - deizm, panteizm, fideizm, monoteizm, politeizm; nie chodzi tylko o to, aby ateizm wyrwać z nomenklatury pojęciowej idolatrii i by stał się on częścią pewnej praktyki, chodzi raczej o to, aby ta praktyka sama nie była zrytualizowanym strumieniem repetycji. Chodzi to, aby „praktyka ateizmu" nie powtarzała praktyk religijnych opartych na „ćwiczeniach w adoracji” i repetycji. W ateizmie chodzi także o inne pojęcie praktyki. „Ateizm” - odwołując się do Judith Butler - jest z pewnością „zapalnym słowem” lub raczej - słowem zapalnikiem ${ }^{37}$. Dlatego może należałoby zapytać o „sprawczość ateizmu” lub zażądać po prostu „ateizmu performatywnego". W jakim sensie performatywnego? Co taki performatywny ateizm miałby wytwarzać? Czy sama praktyka profanacyjna może wytworzyć ateizm? Czy są podstawy do tego, aby mówić o „fabrykacji ateizmu”, tak jak mówiliśmy o fabrykacji obrazów idolatrycznych? I czy taka fabrykacja lub "produkcja ateizmu" nie skazywałaby go na wszystkie wcześniej opisane słabości idolatrii?

Twierdzę, że jak długo pojmujemy praktykę, na wzór słownika zaprojektowanego przez Marcela Maussa ${ }^{38}$ lub Pierre'a Bourdieu, tj. jako „technikę przyswajania”,,,technikę społeczną",,,zbiór nawyków”, ,,system trwałych dyspozycji”, funkcjonujących jako „zasada generująca i organizująca ludzkie zachowania", tak długo ustanowienie ateizmu jako praktyki ateistycznej wydaje się kłopotliwe ${ }^{39}$. Tradycji habitusu chciałbym tutaj przeciwstawić tradycję "maniery", którą wywodziłbym z filozofii Michela de Montaigne'a ${ }^{40}$. Dla Montaigne’a całe życie było manieryczne i chimeryczne. „Lepiej czasem skłonić prawa, aby to chciały, co mogą, skoro nie mogą tego, co chcą" - powiada lapidarnie Montaigne w swoich esejach, a potem systematycznie wprowadza nas w świat swoich manier.

Czym jest maniera? „Maniera - twierdzi Agamben - nie jest ani rodzajem, ani bytem jednostkowym - jest przykładem, czyli jakąkolwiek pojedynczością"41. To ważne stwierdzenie, albowiem sugeruje ono „pojedynczość”

\section{J. Butler Walczące słowa. Mowa nienawiści i polityka performatywu.}

M. Mauss Sposoby posługiwania się ciałem, w: tegoż Socjologia i antropologia, przeł. M. Król, K. Pomian, J. Szacki, wstęp C. Lévi-Strauss, PWN, Warszawa 1973, s. 533-565.

P. Bourdieu Szkic teorii praktyki, poprzedzony trzema studiami na temat etnologii Kabylów, przeł. W. Kroker, Kęty 2007; P. Bourdieu Zmysł praktyczny, przeł. M. Falski, Wydawnictwo UJ, Kraków 2008.

M. de Montaigne Próby, przeł. T. Boy-Żeleński, PIW, Warszawa 1957.

G. Agamben, Wspólnota, która nadchodzi, s. 34 . 
manier. Maniera nie jest ani bytem jednostkowym, ani bytem ogólnym, nie jest ani „jednostkowością zdarzenia”, ani „ogólnością pojęcia”. Agamben przytomnie dodaje również, że „maniera” (termin maneries) nie pochodzi od czasownika manere oznaczającego "trwać”, ani nawet od słowa manus, oznaczającego „ręka”, ,dłoń”, a przy bardziej odważnym tłumaczeniu „siła robocza”, ale od manare, wskazującego na „byt w zdolności do wyłaniania się". Maniera to byt, który nie zakłada żadnej swojej istoty, żadnej przedustawnej definicji. Co to oznacza? Oznacza to, że byt, który wyraża się bez reszty w swych objawach jest bytem nieustannie rodzonym przez swoją manierę, a byt zmanierowany to byt ściśle ateistyczny. Działanie w oparciu o maniery stanowi jedyną praktykę ateistyczną.

Jak zatem należy sobie wyobrazić praktyki ateistyczne? Czy należy je sobie wyobrazić jako praktyki zmierzające do profanacji, tj. wyprowadzenia rzeczy z nieużytkowej przestrzeni świętej w użytkową przestrzeń świecką ${ }^{42}$ ? Czy też te praktyki należy sobie wyobrazić jako praktyki propagacji błędu, uznania błędu za „błąd dobroczynny” «3? Wiemy przecież, że to, co robimy i mówimy, nie jest funkcją naszych intencji. Sprzeczność performatywna to sytuacja w której działanie samo tworzy „znaczenie”, często podważające intencję. Czy jednak stwierdzenie możliwej niewspółmierności między intencją i działaniem - mówienie nie tego, co chce się powiedzieć, wypowiedzią a działaniem - robienie nie tego, co się mówi, czy wreszcie intencją a działaniem - robienie nie tego, co się zamierzało, zagraża teistycznym warunkom polityki, czy też przeciwnie sprzyja „praktyce ateistycznej”? Czy niewspółmierność mowy i działania nie sugerowałaby ciągłą obecność gry pozoru, gry idola, oddziaływania fetysza?

Rancière zwraca uwagę na to, że demokracja jest ustrojem politycznym, który nie jest ustrojem politycznym, jest raczej bazarem ustrojów, polityczną szatą arlekina, rodzajem „skandalu równości” ${ }^{4}$, a zatem „ustrojem manierycznym". Od czasów Platona demokracja odnosi się do takiego życia, którego nie da się pogodzić z żadną uporządkowaną formą zarządzania życiem. Demokracja jest "ateizmem wcielonym" i zmaterializowanym; demokracja to po prostu rządy ateistów. Maniera jest trudna do zatrzymania. Maniera jest fabryką dekonstrukcji, która sama znajduje się procesie dekonstrukcji. Co może

\footnotetext{
42 G. Agamben Profanacje, przeł. M. Kwaterko, PIW, Warszawa 2006.

43 J. Butler Walczące słowa. Mowa nienawiści i polityka performatywu.

44 J. Rancière Nienawiść do demokracji, s. 47.
} 
stanowić autoryzację praktyki ateistycznej? Otóż, nie ma takiej autoryzacji, albowiem jedyną autoryzacją praktyki ateistycznej jest samo praktykowanie rozspojonych i rozspajających manier. Demokracja to rządy ateistów. Ateista - rozumiany jako człowiek odmawiający uprawiania jakichkolwiek kultów i demokracja - rozumiana jako ustrój odrzucający podział na rządzących i rządzonych, wzajemnie siebie wymagają i się dopełniają.

Pytam, kiedy taka sytuacja jest możliwa? Kiedy możliwy jest w pełni zmanierowany świat? I odpowiadam: wtedy i tylko wtedy, gdy rządzi ateizm, który jest brakiem, a nawet odmową wiary we wszelką „naturalną” albo „uzasadnioną" hierarchię. Powiedziałbym, że tylko ateiści gwarantują etyczność miasta, pozwalają oddalić się „bogom na uwięzi”, nie oczekują już czwartej gwarancji czystości świata, gdyż nie oczekują żadnych gwarancji czystości, wierzą po prostu w „nieczystość” i w „nieczystości”. W przeciwieństwie do agnostyków nie zawieszają wszystkich racji bez rozstrzygnięcia, nie zawieszają także aktu woli. Nie można pytać, czego chce agnostyk, ponieważ on niczego nie chce, ale można pytać, czego chce ateista? Czego zatem chce ateizm? Ateizm chce ustanowienia demokracji poprzez zmanierowanie świata. Zgoda na ateizm nie jest zgodą na "prosty ateizm” ani "prawie ateizm”, ani „ateizm w rozkroku”, ale na „ateizm robiący demokrację”. Ateizm zaistnieje, mimo że wciąż istnieje wiara w transcendencję, byt wertykalny i państwo imperialne. Filozofia stanie się ateistyczna, gdy jej żywiołem przestaną być pojęcia, a stanie się nim życie zmanierowane. 


\section{Abstract}

\section{Szymon Wróbel}

UNIVERSITY OF WARSAW

From Atheism of the Concept towards Atheism without the Concept

Wróbel explores 'atheism of the concept,' which for him gives rise to the 'cult of the concept'. He asks if 'atheism of the concept' might not be a vestige of theistic thinking, which we ought to overcome. He also asks if an'atheism beyond the concept' might be possible, but this forces him to reflect on the very notion of the concept. He remains conscious of the fact that the 'concept' is not 'beyond life' but is 'a way of life' - one among many. This is why Wróbel does not present'atheism of the concept' as opposite to 'atheism without the concept,'in as far as'the concept' is not the opposite of 'life.'Atheism without the concept' is rather an atheistic practice and concerns 'lifestyle' rather than the content of'convictions' or'conceptual forms'. In an atheistic world, time is not about activating potential; it is not the reality of time that creates the reality of events, but the events themselves allow the course of time to unfold. The cosmos thus understood is not governed by any timeless principle, it must rely on the pure immanence of its being outside of rectitude and beyond the conceptual.

\section{Keywords}

concept atheism, factish, fetish, idolatry, manner, concept of atheism, practice 